\title{
State Administrative Court as a Means to Realize Justice
}

\author{
Weda Kupita $^{1 *}$ \\ ${ }^{1}$ Faculty of Law, Jenderal Soedirman University, Purwokerto, Central Java, Indonesia
}

\begin{abstract}
The existence of 4 (four) kinds of judicial environment in the Judicial Authority in Indonesia, shows a judicial system adopted in Indonesia. the State Administration Judiciary is a apart of judicial power under the Supreme Court that examines cases relating to state administrative decisions. This article discusses the resolution of disputes as a result of the issuance of state administrative decisions in the state administrative court. This problem will be answered by using the legislation approach and case approach, with analysis using qualitative methods. To test a state administrative decision, a tool is needed to validate a state administrative decision. standard for testing the validity of the state administrative decisions in the examination at the state administrative court, are the laws and regulations and the general principles of good governance.
\end{abstract}

\section{Introduction}

The explanation of the 1945 Constitution explains that the Indonesian state includes a legal state in the concept of "rechtsstaat". As a concept of a rule of law, rechtsstaat is a concept of a legal state originating from Continental Europe, with its legal system civil law. This model of the rule of law applies in the Netherlands, Germany and France[1]. According to Freidrich Yulius Stahl, an element of the rule of law (rechtsstaat), namely:

1. Recognition and protection of basic human rights;

2. Separation or distribution of powers to guarantee those rights;

3. Government based on legislation; and

4. Administrative court in disputes[2].

To realize one of the elements of the rule of law, the provisions concerning the Judicial Power in Article 24 paragraph (1) of the 1945 Constitution stipulate that: "judicial power is an independent power to administer the judiciary to enforce law and justice". Further regulation regarding the judicial power institution is regulated in Law Number 48 of 2009 concerning Judicial Power, which in the provisions of Article 18 Paragraph (2) regulates 4 judicial environments namely: "Judicial power is carried out by a Supreme Court and the judiciary under him in the General Courts, the Religious Courts Environment, Military Courts Environment, State Administrative Courts, and by a Constitutional Court "[3].

\footnotetext{
* Corresponding author : goweddodo1@gmail.com
} 
The existence of 4 (four) kinds of judicial environment in the Judicial Authority in Indonesia, shows a judicial system adopted in Indonesia, According to the Big Indonesian Dictionary formulated that the notion of the system is "interrelated elements that form a totality" or "something regular from view"[4]. According to Lily Rasjidi, the system is a complexity of elements that are formed in one unit of interaction (process), which are interdependent, form unity, cannot be understood partially, the parts are in the whole[5]. In simple terms, the meaning of the system is a unitary arrangement, where each element in it is not considered its essence, but is seen according to its function to the overall similarity of the arrangement.

Understanding of the Judiciary can be interpreted as a process of working of a court institution, which shows the existence of certain procedures. In Article 18 of Law Number 48 of 2009 concerning Judicial Power, the word "judiciary" is preceded by the word "environment", it can be interpreted to mean the word "justice" means the function of judging from a court environment, or the process taken in finding and finding justice. Whereas the "court" connotes as an official agency which is one of the perpetrators of the trial function, which is supplemented by official officials who are judges[6].

Based on the understanding of the system and understanding of the judiciary, the judicial system in Indonesia can be interpreted as "an orderly and interconnected arrangement related to the examination and termination of cases carried out by the court, whether it is a court within the general court, religious justice, the military court, as well as the state administrative court, which is based on the views, theories and principles in the judicial field that apply in Indonesia ".

The purpose of the Republic of Indonesia is the creation of a just and prosperous society. Fair and prosperous society is a combination of judicial functions and economic functions. Fair is closely related to justice as one of the objectives of the law. To achieve this goal justice and prosperity require law enforcement efforts by taking action against any violation of the law consistently with strict sanctions for violators. Law enforcement is also to create legal certainty for the community. In an effort to ensure that legal certainty is needed by a law enforcement agency, in this context the judiciary can be said to be a law enforcement agency.

According to Sudikno Mertokusumo, the judiciary is the implementation of the law in the concrete case of the claim of rights, which function is carried out by a body that is independent and held by the state and free from any influence or anyone by giving a binding decision that aims to prevent "eigenrichting" (playing judge yourself) [7].

Another term of the State Administration Judiciary is the State Administrative Court (Peratun), which according to Article 24 paragraph (2) of the 1945 Constitution and Article 18 of Law Number 48 of 2009, is the name of a judicial environment in the judicial authority in Indonesia whose authority dealing with State Administration matters resulting from the issuance of the State Administration Decree. In the context of Peratun as a means to realize justice Article 4 of Law Number 9 of 2004 stipulates that the State Administrative Court is one of the perpetrators of judicial power for the people seeking justice against State Administration disputes. Furthermore Article 47 of Law Number 5 of 1986 stipulates that the State Administrative Court is in charge and authorized to examine, decide, and resolve State Administrative disputes. The definition of a State Administration dispute is a dispute in the field of State Administration which is caused by the issuance of a State Administration Decree.

This paper will discuss the authority of Peratun in adjudicating State Administration disputes between individuals or civil legal entities against State Administration agencies or officials, such disputes occur as a result of KTUN issuance by State Administration agencies or officials, where KTUN is impaired by a person or legal entity civil. In relation to the title of this paper, Peratun as a court institution is used as a means to realize justice for litigants. 


\section{State Administrative Court as a Means to Realize Justice}

Peratun as a means of realizing justice, means that Peratun is intended to provide protection to the people against the occurrence of government actions (in the form of KTUN) which are considered to violate the law. Contrary to the law (onrechtsmatig) in the context of Article 53 paragraph (2) Law Number 9 of 2004 means violating laws and / or violating general principles of good governance. Citizens who are harmed by state administrative actions have the right to file a lawsuit in Peratun in accordance with the legal protection function for the people of Peratun.

Associated with the protection of human rights, the legal protection function for the people by Peratun can be put in the framework of the principle of protection of human rights, namely bridging natural law and positive law, namely by making natural rights as positive legal rights (positive legal rights). ); and balancing the role of government as a threat to freedom with the role of government as a tool needed to promote mutual welfare[8].

Peratun as a judicial institution, is inseparable from the existence of judges in it, the duty of a judge is to take decisions about people's personal rights fairly[9]. Institutionally and in the context of control, it is necessary to maintain the balance of legislative, executive and judicial power. Associated with the perspective of justice, the virtue of justice is a typical virtue of a judge he runs on the application of law in the judiciary[10].

In connection with the authority of Peratun in canceling a KTUN, Peratun acts as a judicial institution intended to harmonize KTUN (beschikking) which is a product of government authority with legislation as the basis for its stipulation, where the law is a product of legislative power, should be based on Pancasila as "Moral basis for Indonesian law order".

Peratun's decision is not enough to only fulfill the legality requirement, but must meet the requirements of morality and justice. As a guardian of morality and justice, the testing of KTUN conducted by Peratun is not only based on benchmarks of conformity with the applicable laws and regulations / written law (wetmatigheid), in the welfare state added to the general principles of good governance as unwritten legal norms (rechtmatigheid benchmarks). It is universally accepted that there are general principles of good governance as an unwritten rule of law that binds the authorities in carrying out their functions[11]. This actually reflects the correction of the juridical positivism paradigm that identifies the law with the law, releases the law from morality, ignores the value of collective community justice.

Kuntjoro Purbopranoto mentioned 13 (thirteen) general principles of good governance, namely: the principle of legal security, principle of proportionality, principle of equality in pangreh decision making (principle of equality), principle of acting the principle of carefullness, the principle of motivation for each pangreh decision (principle of motivation), the principle of not mixing authority (principle of non-misuse of comptence), the principle of fair play (principle of fair play), principle of justice or fairness (principle of reasonableness or prohibition of arbitrariness), the principle of responding to reasonable expectations (principle of raised expectation meeting), the principle of eliminating the consequences of a null and void decision (principle of undoing the consequences of an annulled decision), the principle of protection of the view of life / personal way of life (principle of protecting the personal way of life), the principle of wisdom (sapientia) and the principle of public interest (principle of public service) [12].

In the Netherlands, there are 7 (seven) of the general principles of good governance that have received a strong legal position through AROB jurisprudence, which is then included in Article 8 paragraph (1) letter d AROB, namely: principle of equality, principle of trust, the 
principle of legal certainty, the principle of accuracy, the principle of giving reasons (motivation), the prohibition of detournement de pouvoir (abuse of authority), and the principle of prohibition of arbitrary acts.

The process of giving a strong legal position to the general principles of good governance parallel with the development of state administrative law, in which the state administrative law doctrine deems it necessary to provide legal protection to the people from government actions that harm the people and the need for guidelines for the government in carrying out its duties, then the principles used by Peratun as the toetinggronden are used to test the validity of KTUN, as well as the basis for deciding on concrete disputes, and then the principles are set forth as material content of the law, for example the material contained in Article 53 paragraph (2) letter b of Act Number 9 of 2004.

Explanation of Article 53 paragraph (2) letter b of Law No. 9 of 2004 states that there are 6 (six) general principles of good governance as a basis for testing in Peratun, namely: legal certainty, orderly state administration, openness, proportionality, professionalism and accountability. The substance of general principles of good governance in the explanation of Article 53 paragraph (2) letter b of Law No. 9 of 2004 is more like a combination of principles which were originally contained in the general principles of good governance as had been developed by the state administrative law doctrine with good governance. The good governance component of the United Nations Development Program (UNDP) version of the Organization for the Economic Cooperation and Development (UNDP) includes: participation, rule of law, transparency, responsiveness, consensus orientation, equity, effectiveness and efficiency, accountability and strategic vision[13].

Based on the description above, the use of good general governance principles as one of the testing grounds (toetsinggronden) against KTUN, can be understood as an effort to achieve maximum justice in the decision in Peratun, as mandated by Article 4 of the Peratun Law. The importance of the general principles of good governance as one of the toetinggronden is to depart from the limitations of legislation (written law) as a toetinggronden who can only reach written law, whereas written law is often unable to achieve social justice for the people. Wetmatigheid van het bestuur does not or does not guarantee the achievement of a prosperous legal state and social justice[14].

The aim of Peratun pursuant to Article 4 of the Peratun Law is to realize justice for the people, parallel with that legal theory of cybernetics considers that law is the center of controlling interpersonal communication, which aims to realize justice as its goal. The law was created by the power holder, who according to the premise that preceded it was called the central organ. The realization of the purpose or control is carried out by controlling the behavior of each individual, avoiding disputes or by applying legal sanctions to a dispute. In this way, every individual is expected to behave in accordance with orders and justice can be realized because of it. This is because the ultimate goal of the law is justice[15]. All efforts related to the law must absolutely be directed to find a legal system that is most suitable and in accordance with the principles of justice[16]. In connection with the legal theory of cybernetics, in order to realize justice, the Peratun Law must be determined in such a way that Peratun has adequate facilities to be able to assess the validity of a KTUN by using a benchmark that is able to bring a sense of justice to the community.

It has been explained above, that the most important goal of law and justice is to achieve justice, Soekanto, stating that justice is a legal duty or is a legal use. Legal justice can be realized if through a law enforcement through a good court institution[16]. A good court institution, so that it will be able to carry out its functions, the court institution must produce a product of a court decision that is not only directed to mere legal certainty, but also must produce a product of fair judgment that can be accepted by the parties to the dispute. So that in fact the existence of law and the court has the ultimate goal of achieving justice. 
Peratun, in the concept of Trias Politics is a judicial institution, or as a government supervisory institution, the supervision of Peratun on government actions in issuing KTUN is not only based on the criteria of written legal principles, but also uses general principles of good governance as legal norms. unwritten. It grows as a result of the interaction between the government and the community which raises the need for an instrument of supervision of state administration officials using unwritten legal norms[15]. The use of general principles of good governance as a benchmark for assessing the validity of KTUN, is also based on sources of state administrative law that place state administration practices as one of the sources of formal law. So that from the practice of state administration can be obtained the state administrative habits that are useful for the formation of state administrative law. The functions of general principles of good governance include guidelines for the implementation of government duties, as a reason for the lawsuit, and by the judge as a benchmark for testing the validity of KTUN. In connection with this function, general principles of good governance can be a filter to determine good state administrative practices and are worthy of being a source of state administrative law.

In a modern state of law, in carrying out government is not only based on written law (law). Because written law has limitations and also not necessarily in line with the sense of justice of the community. Likewise in the application and creation of law by a judicial institution, it is certainly not only guided by written law, but based on the law on judicial power, judges as well as acting as law (law), judges are also given the freedom to explore and creating a law for a case, especially in terms of void or obscure rules.

General principles of government that are well defined as unwritten legal norms through Peratun's decision to complete written legal norms. General principles of good governance are needed to test the substance of justice in the use of state administrative authority, which is not always affordable by testing based on written legal norms. Thus it can be emphasized that in order to be used as a means to bring about justice, Peratun must be able to evoke the general principles of good governance as a toetinggronden to examine a government action in the form of KTUN, and all of it is ratified so as to bring justice to the parties to the dispute.

\section{Conclusion}

The aim of the establishment of Peratun, in accordance with Article 4 of the Law on Peratun is to realize justice for the people who seek justice in the State Administration dispute. State Administrative Disputes can occur as a result of KTUN's exit. In the State Administration Law, KTUN is a form of government action, a KTUN can be an object of a State Administration dispute, if the KTUN is detrimental to the sense of justice for the community (person or civil legal entity). Peratun's authority is as a court institution that hears and then cancels a KTUN. In order to cancel KTUN, a benchmark (toetsinggronden / test equipment) is needed to test the validity of a KTUN. Benchmarks for testing the validity of KTUN, namely the laws and regulations and the general principles of good governance. Legislation is more meant as written law, while general principles of good governance are more interpreted as unwritten law. The general principles of good governance as a law that lives in the midst of a sense of public justice, will become a main pillar for Peratun to realize the main goal of Peratun, namely as a means of achieving justice for justice seekers in the State Administration dispute. 


\section{References}

1. A. M. Fahmal, The Role of General Principles of Eligible Governance in Realizing a Clean Government, (UII Press, Yogyakarta, 2006)

2. 2 Ridwan H.R, State Administrative Law, (Raja Grafindo Persada, Jakarta, 2013)

3. Z. Harahap, Procedural Law of State Administrative Court, (Raja grafindo Persada, Jakarta, 2001)

4. Departemen Pendidikan Nasional Indonesia, 2005, Big Indonesian Dictionary (KBBI), Edisi Ketiga, Balai Pustaka

5. L. Rasjidi, Law as a System, (PT Remaja Rosdakarya, Bandung, 1993)

6. A. Ramasari, Justice System in Indonesia, dalam http://www.google.com, accessed on August 20, 2018.

7. S. Mertokusumo, Justice System in Indonesia, dalam http://google.com, diakses tanggal 20 Agustus 2018

8. P. M. Hadjon, Legal Protection for the People: A Study of its Principles, Handling it by the Court in the General Courts and Establishment of State Administrative Courts, (Bina Ilmu, Surabaya, 1997)

9. T. Huijbers, Legal Philosophy in Historical Paths, (Kanisius, Yogyakarta, 2006)

10. A. Sidharta, Legal Reflection, (Citra Aditya Bakti, Bandung, 1996)

11. Muksan, The realization of a clean and authoritative government in a welfare state, Inaugural Speech for Professor of the Faculty of Law, Pidato Pengukuhan Jabatan Guru Besar Fakultas Hukum Universitas Gajahmada, 15 Maret 1999

12. P. M. Hadjon et.al, Introduction to Indonesian Administrative Law, (Gajahmada University Press, Yogyakarta, 1994)

13. M. Fahmal, 2006, The Role of General Principles of Eligible Governance in Realizing a Clean Government (UII Press, Yogyakarta, 2006) see also H. Salmon, The Existence of State Administrative Courts in Creating a Good Government, SASI, 16:4 (2010)

14. Azhary, State of Indonesian Law, Juridical Analysis of the Elements, (UI Press, Jakarta, 1998)

15. L. Rasjidi, IB. W. Putra, 1993, Law as a System, (Remaja Rosdakarya, Bandung, 1993)

16. A. G. Anshori, Philosophy of Law (Gajahmada University Press, Yogyakarta, 2006) 